\title{
Emancipate the Quartertone: The Call to Revolution in Nineteenth-Century Music Theory
}

Daniel K. S. Walden, Harvard University

\begin{abstract}
A BSTRACT
In 1852, the theorist Johanna Kinkel urged musicians to "emancipate the quartertone [for] a new world of sound!" Her call to arms was quickly countered by Wolfgang Heinrich Riehl, who denigrated such "enharmonic" sounds as "effeminate" in contrast to traditional German diatonicism. This debate occurred during the contemporaneous development of experimental keyboards that could enable Kinkel's musical "emancipation," featuring up to fifty-three equally tempered divisions of the octave in approximation of the pure intervals of just intonation. This article describes two such instruments as case studies: T. P. Thompson's enharmonic organ for the "abolition" of temperament, and Tanaka Shôhei's enharmonium for the restoration of music's "natural purity." I show how the language these theorists used reveals the larger political and cultural forces shaping the late nineteenth-century development of music theory and comparative musicology and trace how their instruments were construed as tools for transnational exchange and the global promotion of European civilization.
\end{abstract}

$\mathrm{n}$ 1852, the musician, novelist, and activist Johanna Kinkel published a startling call to arms: "Emancipate the quartertone, so you will have a new world of sound!"' This rallying cry announced the endpoint of a progress toward the appreciation of eversmaller musical intervals. In earlier ages, "not the ear but mathematical calculations were used to determine which intervals sounded good or bad": fifths and octaves were permissible, but thirds, the source of the sensual pleasure of contemporary music, were rejected as "intolerable dissonances." 2 The limitations of this impoverished musical vo-

1. "Emancipirt die Vierteltöne, so habt ihr eine neue Tonwelt!" (Johanna Kinkel, Acht Briefe an eine Freundin über Klavier-Unterricht [Stuttgart: J. B. Cotta, 1852], 78).

2. "In den frühesten Jahrhunderten christlicher Zeitrechnung, wo man nicht das Ohr, sondern die mathematische Berechnung entscheiden ließ, welche Intervalle wohl oder übel klingen müßten, schritten

History of Humanities, Volume 2, Number 2. http://dx.doi.org/10.1086/693317

(C) 2017 by Society for the History of the Humanities. All rights reserved. 2379-3163/2017/0202-0002\$10.00 
cabulary, Kinkel writes, eventually became clear. Musical progress underwent a slow but inevitable revolution leading to the triumphant rise of triadic harmony: "Now we owe thanks to the third for sequences of the most beautiful harmonies, which for centuries now . . . have refreshed our souls." ${ }^{3}$ Nevertheless, a second revolution was overdue. Harmonic resources were once again exhausted, and as modern melodies sound more and more like superficial imitations of earlier precedents, "the ear sighs for something new and previously unheard." ${ }^{4}$ The way to shatter the tedium of contemporary music, she urges, is to introduce a new class of intervals into compositional vocabulary, those even smaller than the semitone. This second musical revolution would be no less radical and disruptive than the first, leading theorists and performers down "unknown pathways" at the end of which subsequent generations, nurtured in the "mother's milk" of "alien sounds" ( fremde Klangen) would ultimately come to acknowledge these "alien" intervals as part of an enriched compositional vocabulary. ${ }^{5}$ Once the microtonal floodgates have "burst open, we are a step even closer to eternal Nature. For then why couldn't we represent in exact tones the strains of the Aeolian harp, the noises of the forest, the magical sounds of water, now imitated only poorly because our so-called whole and half-tones lie too heavy-set and imperfectly spaced from one another? Nature possesses not only quarter- or eighth-tones, but an endless scale broken down into the finest of sound-atoms!"6 Kinkel urges that theorists ought also to acknowledge that composers have already been straining against the barrier of twelve-tone equal temperament. She offers the example of Frédéric Chopin, whose scores are filled with passages she identifies as enharmonic, such as measures 27-30 of the A-flat "Impromptu," opus 29, where she claims "the enharmonic repetition of the previous $\mathrm{C}$ is effected by means of a $\mathrm{D}$-double-flat in order to create the finest distinction of which our harmony is thus capable." This is the sound of the "spirit voices

die mehrstimmigen Sätze in Quinten und Oktaven neben einander fort, denn Terzen galten für unerträgliche Dissonanzen" (ibid., 76).

3. "Nun verdanken wir ihr die Reihenfolge der herrlichsten Harmonien, die seit Jahrhunderten ... unsere Seele erfrischten” (ibid., 77-78).

4. "das Ohr seufzt nach ganz Neuem, Unerhörtem" (ibid., 78).

5. "unbekannte Bahnen ... doch vielleicht schon begrüßt die nächst- oder drittfolgende Generation, wenn sie erst mit der Muttermilch die fremden Klänge eingesogen hat, in ihnen eine frischerstandene, doppelt reiche Kunst" (ibid., 75-78).

6. "Ist einmal diese Pforte gesprengt, so sind wir abermals um einen Schritt näher den ewigen Naturlauten: denn warum können wir die Aeolsharfe, das Waldesrauschen, die zauberischen Laute des Wassers nicht treu in Töne fassen, nur schwach nachahmen, weil unsere sogenannten ganzen und halben Töne zu plump und lückenhaft auseinander liegen, während die Natur nicht bloß Viertelund Achteltöne, sondern die unendliche, kaum in Klang-Atome zersetzte Skala besitzt!" (ibid., 79). 

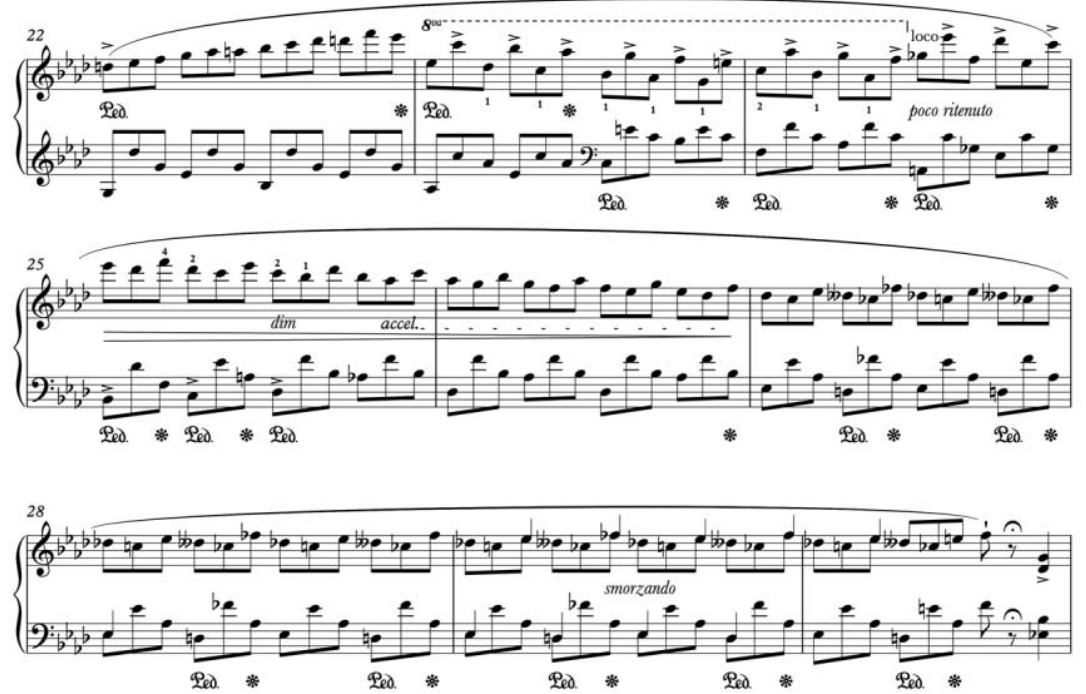

Figure 1. The passage in Frédéric Chopin's "Impromptu” in A-flat major, op. 29, cited by Johanna Kinkel as an example of "enharmonic repetition" (measures 22-30). Excerpt based on the first French edition (Paris: Chez Maurice Schlesinger, 1837).

whispering in the spheres ... which only the soul can perceive," of a music fully emancipated, set free to roam unfettered through the wilds of nature (see fig. 1).?

For Kinkel, microtonalism and the related concept of enharmonicism thus point toward a music-theoretical revolution: the development of a new conceptual framework for understanding what constitutes musical nature. Theorists are assigned the task of uncovering the hidden microtonal networks of tones concealed beneath the equal-tempered surface of historical musics, as well as of promoting enharmonic compositional development. Kinkel's account of this musical revolution may sound hyperbolic, but there is no mistaking the serious intent of her political subtext. Her overview of musical history as a succession of liberating tonal revolutions, in which a previously subordinate class of intervals takes over the responsibility of determining new types of structural organization, recalls the revolutionary summons to the suppressed classes by her fellow exile and associate Karl Marx. Her vocabulary is also steeped in allusions

7. "hier ist die enharmonische Wiederholung des vorherigen $c$ durch desdes benutzt, um den feinsten Unterschied hervorzubringen, der in der Harmonie bisher möglich war. Es ist die Sprache, in welcher die Geisterstimmen der Sphären flüstern . . . nur von der Seele geahnt werden sollten" (Johanna Kinkel, “Chopin als Komponist," Deutsche Revue 27 [February 1902]: 220, quoted and translated in Linda Siegel, "Johanna Kinkel's 'Chopin als Komponist' and Other Musical Writings: Untapped Source Readings in the History of Romantic Music," College Music Symposium 43 [2003]: 112). 
to the campaigns for modern political and social reform, with a specific emphasis on women's emancipation, which she championed as a prominent political organizer in both Bonn and London. ${ }^{8}$ These allusions were certainly not lost on critics like Wilhelm Heinrich Riehl, who attacked her arguments in his album Hausmusik, a collection of fifty lieder prefaced by a lengthy introduction touching on aesthetic, nationalist, and antidemocratic themes. Riehl, better known today as a sociologist and cultural historian than a music theorist or composer, contrasts an idealized music that is reflective of the robust masculine spirit of the Volk to the "effeminate, smug, sickly, tattered, and overly feminine [weibische, blasirte, kranke, zerrissene, überweibliche]" music practiced by salon musicians and artists such as Kinkel: "Through the influence of the French, Polish, and Hungarians, our German musical art, which was so healthy and fresh a mere fifty years ago, has degenerated into veritable whimpering. Cats have already 'overcome' the system of whole and half tones; they have already emancipated the well-known quartertones, which, as Johanna Kinkel dreams up, sigh for their deliverance." ${ }^{\text {"9 }}$ Riehl characterized his own compositional outlook as "so reactionary as to not contribute to emancipating the quartertone, or sighing for its liberation. . . He who is conservative in social politics by conviction, will also be so in his music, especially in his Hausmusik." ${ }^{10}$ While Kinkel searches for new enharmonic theories that liberate music from a rigid framework imposed by the twelve keys of each octave on the keyboard, pointing toward a musical future that is at once more natural and more modern, Riehl affirms a traditional vision of music-making in which the roles each person plays are constrained by gender and economic class and in which the pitches already available on the piano are sufficient.

The Kinkel-Riehl episode reveals that debates about microtonalism, and issues of tuning and temperament, were not just about the physical properties of pitch. This area

8. For more on Johanna Kinkel's extraordinary biography, see Monica Klaus, Johanna Kinkel: Romantik und Revolution (Cologne: Böhlau, 2008). Kinkel's most prominent position in German radical politics was as editor of the revolutionary Neue Bonner Zeitung. After leaving Bonn and the turmoil following the 1848 revolutions for London, she became known as the Emigrantenmütter for her important role in coordinating financial assistance and other forms of support for German Democrats living in exile after the turmoil of the 1840s.

9. "Durch den Einfluss von Franzosen, Polaken und Magyaren ist unsere vor fünfzig Jahren noch so kerngesunde und frische deutsche Tonkunst in ein wahres Gewinsel ausgeartet. . . . Die Katzen haben nämlich bereits das System der ganzen und halben Töne 'überwunden,' sie haben jene bekannten 'Viertelstöne' bereits emancipirt, die wie Johanna Kinkel träumt, nach ihrer Erlösung seufzen" (Wilhelm Heinrich Riehl, Hausmusik [Stuttgart: Cotta, 1855], xi).

10. "Der Tonsetzer war nun so reaktionär, in den vorliegenden Liedern zu dieser Emancipation der nach ihrer Erlösung seufzenden Viertelstöne nicht entfernt mitzuwirken. . . . Wer in der Social-Politik aus Ueberzeugung conservativ ist, der wird es auch in der Musik seyn, absonderlich in seiner Hausmusik" (ibid., xi-xii). 
of research, of interest to acousticians, anthropologists, and musicians, was a highly politicized field of music-theoretical discourse. The claims about microtonalism and enharmonicism staked by key figures in the nineteenth century are inseparable from their reactions to global political developments in the areas of women's rights, abolition, globalism, capitalism, industrialization, and colonialism. Kinkel's argument is fruitfully understood in the context of efforts by international music theorists and practitioners who conceived of the study of tuning and temperament as indispensable to understanding both nature and the enharmonic origins of all global musics. This branch of study could also point toward how music theory might play a key role in implementing the social, cultural, and political transformations necessary to promote a more perfect modern society.

Kinkel did not propose replacing the piano with a new kind of keyboard that could perform the enharmonic intervals that she identified in Chopin, but a number of contemporary musicians and instrument builders did just that, for they saw instruments as essential tools for training musicians to appreciate the implications of their theoretical ideas. Dozens of enharmonic harmoniums, organs, and pianos with as many as fifty-three divisions of the octave were designed over the course of the nineteenth century for investigating the sonorities that can be constructed from accretions of microtonal intervals, the "sound-atoms" (Klang-Atome) that Kinkel described. Such instruments were designed, built, and displayed around the world, notably in England, Scotland, Germany, Italy, the United States, Mexico, and Japan. ${ }^{11}$ They were developed as tools for embodying claims like Kinkel's about musical and social life, invented to retrain performers to better perceive and reproduce the intervals necessary for creating modern musical practices that could be labeled as "ideal," "natural," and "pure." Their inventors offered a variety of competing justifications for these innovations; some promoted them in an effort to restore the rich sonorousness the Western musical canon had once enjoyed when it employed a more perfect intonation system, while others saw the instruments as bulwarks against the colonial spread of Western tuning practices, capable of assisting in the preservation of local and indigenous musical traditions that employed unequal divisions of the scale. These instruments repurposed and reconfigured the musical keyboard as a form of cultural critique, one that aimed to point music theory toward political orientations that were disquieting to theorists wedded to affirming the superiority of traditional European musical practices.

11. For a partial survey, see Luca Conti, Suoni di una terra incognita: Il microtonalismo in Nord America (1900-1940) (Lucca: Libreria musicale italiana, 2005); and Patrizio Barbieri, Enharmonic Instruments and Music 1470-1900 (Rome: Il Levante Libreria Editrice, 2008). 
What follows are two case studies, sketching contrasting scenes in this musictheoretical battleground: first, of Thomas Perronet Thompson, whose enharmonic organ provides insight into the dynamics of mid-nineteenth-century London; second, of Tanaka Shōhei, inventor of the enharmonium, which provides insight into transnational links between turn-of-the-century Berlin and Japan. Both recognized, like Kinkel, that there was a political urgency to the musical topics they were addressing. The instruments Thompson and Tanaka designed were also for musical demonstrations of the theories behind "just intonation," a system whereby the intervals between pitches correspond to "natural" whole-integer ratios (e.g., $1: 2=$ octave, $2: 3=$ fifth, $3: 4=$ fourth), rather than irrational proportions (e.g., $1: 2^{7 / 12}=$ fifth, $1: 2^{5 / 12}=$ fourth). Both were also named for the ancient Greek "enharmonic" genus of melody, whose intervals these two inventors believed were related to those of just intonation. A review of this history can provide insights into the cultural dynamics at play during an important period in the development of musical theory and comparative musicology during the late nineteenth and early twentieth centuries. It will also trace how these instruments could serve as tools for the global promotion of European civilization, as well as assets in transnational musical exchanges between nation-states nursing ambitions for a major role on the modern world stage.

\section{THOMPSON'S ABOLITION OF MUSICAL TEMPERAMENT}

Several months after Johanna Kinkel arrived in London as a refugee from Bonn and the political turmoil after the 1848 revolutions, the Great Exhibition of London opened in Hyde Park, a thirty-minute walk from her lodging in St. John's Wood. The exhibition featured marvels from across the British Empire in the newly constructed Crystal Palace, a monumental glass and iron temple dedicated to the products of free trade and Victorian industrialization that were to revolutionize civilization and culture. Charles Dickens and Richard Horne rhapsodized about the event in the weekly magazine Household Words, writing that from the assemblage of items on display viewers could recognize "the progress of humanity, step by step, toward a social condition in which nobler feelings, thoughts, and actions, in concert for the good of all, instead of in general antagonism, producing a more refined and fixed condition of happiness, may be the common inheritance of great and small communities, and of all those nations of the earth who recognise and aspire to fulfill their law of human progression." ${ }^{2}$ The event also told a cautionary tale about the dangers of trade protectionism, describing "the comparison between Stoppage and Progress, between the exclusive

12. Charles Dickens and Richard Horne, "The Great Exhibition and the Little One," Household Words 3, no. 67 (1851): 356. 
principle and all other principles, between the good old times and the bad new times, between perfect Toryism and imperfect advancement." ${ }^{13}$ The grandeur and internationalism of the Great Exhibition affirmed the industrial supremacy of a Victorian Britain bolstered by the commercial contacts achieved through international empire, as well as the high ethical and moral values of a technological futurism that predicted the seemingly limitless possibilities of social progress and engineering through mechanical design.

The North Transept Gallery featured stations dedicated to British marvels in the wide-ranging fields of porcelain, beehives, miscellaneous manufactures, small wares, and musical instruments. Here spectators could find no fewer than three recently invented enharmonic instruments featuring microtonal divisions of the octave: a twenty-four key "bichromatic" seraphine, or harmonium, invented by Robert Snell of London; ${ }^{14}$ an enharmonic guitar, "capable of being arranged in the perfect ratios for upwards of 20 keys," built by Louis Panormo; ${ }^{15}$ and most prominently, an "enharmonic organ" built by T. J. F Robson, "capable of executing with the perfect ratios in 18 keys; or in 20 with the exchange of one of two pipes in the octave, for the keys of five and six flats." 16 The latter two instruments were designed by Colonel Thomas Perronet Thompson, Member of Parliament for the constituency of Bradford, who had been publishing treatises, articles, and announcements about his enharmonic designs for over two decades. Thompson had made his name as an outspoken proponent of free trade, as a prominent independent radical critic of the slave trade, and as coowner of the Westminster Review, a quarterly journal that served as the official publication of the Philosophical Radicals, whose members included Jeremy Bentham, John Stuart Mill, and Francis Place. Thompson had served in the Royal Navy and British Army for twenty-six years, fulfilling appointments to India, the Persian Gulf, and Sierra Leone, from where he was recalled by William Wilberforce from his position of governor for revealing that slavery, though officially banned, had in essence continued through a system of compulsory "apprenticeship." Thompson combined a fervor for abolitionist causes with support for the global promotion of civilization, however, without evincing much awareness of the extent to which liberal advocacy of "universal" concepts might result in oppression of local cultures, regardless of whether the ultimate goals were thought of as egalitarian. He thus viewed education in European

13. Ibid., 360.

14. Official Catalogue of the Great Exhibition of the Works of Industry of All Nations, 2nd ed. (London: Spicer Brothers, 1851), 68 (no. 528).

15. Ibid., 68 (no. 525).

16. Ibid., 69 (no. 559). 
musical tradition as essential for promoting the development of civilization in Britain and abroad, by refining cultural, physical, and political sensibilities. ${ }^{17}$

In one of his early articles about enharmonicism, Thompson left little doubt as to the political objectives underlying his call for a revolution in music theory: "This is a piece of musical radicalism; and like other pieces of radicalism, it will succeed in the end if it is right." 18 His detractors are "enemies of "theory," merely "blundering on by the rule of thumb," and, worst of all, "musical Tories." ${ }^{19}$ Just intonation is the best type of intonation for musical practice because it is the most "natural," employing simple harmonic ratios that also correspond to the proportions of the "music in the planets" discussed in Platonic traditions. ${ }^{20} \mathrm{He}$ claims to have revealed through detailed analysis of classical texts that the ancient Greek enharmonic genus had represented a failed attempted at developing a more natural system for musical practice. Now, through just intonation, that goal could finally be achieved. As civilization is only great if it is in tune with the natural, Thompson suggests, it is ethically and morally imperative that the next British generation, that of his own daughter, be educated in the principles of just intonation, the most natural tuning system of all. The community that can understand the nature of perfect musical harmony might also learn to dwell in perfect harmony.

For Thompson, enharmonic instruments are essential devices not only for training performers to produce and recognize just intonation intervals but also for teaching them to disdain equally tempered ones. The first instrument he devised was the "enharmonic guitar," which used a complicated system of movable frets to facilitate performance in twenty different keys. Not long afterward, Thompson developed a preliminary model of the "enharmonic organ," featuring twenty-nine divisions of the octave; a second more elaborate version, first unveiled in 1850, was the one on display at the Great Exhibition. This offered an increased range with forty-two divisions and was described in detail in Thompson's treatise Theory and Practice of Just Intonation: With a View to the Abolition of Temperament. The title of this text, reprinted almost a dozen times over the next two decades, explicitly analogized the system of equal temperament systems with slavery. Thompson suggested that the glories of the ancient Greek golden age could be revived by promoting choral practices in enharmonies reflective of the ideals of an equitable society (see figs. 2 and 3 ).

17. For more biographical information, see L. G. Johnson, General T. Perronet Thompson, 17831869 (London: George Allen \& Unwin, 1957); and Michael Turner, Independent Radicalism in Early Victorian Britain (Westport, CT: Praeger, 2004).

18. T. P. Thompson, "Enharmonic of the Ancients," Westminster Review (April 1, 1832), reprinted in Exercises, Political and Others (London: Effingham Wilson, 1842), 2:99.

19. Ibid., 2:100.

20. Ibid., $2: 158$. 


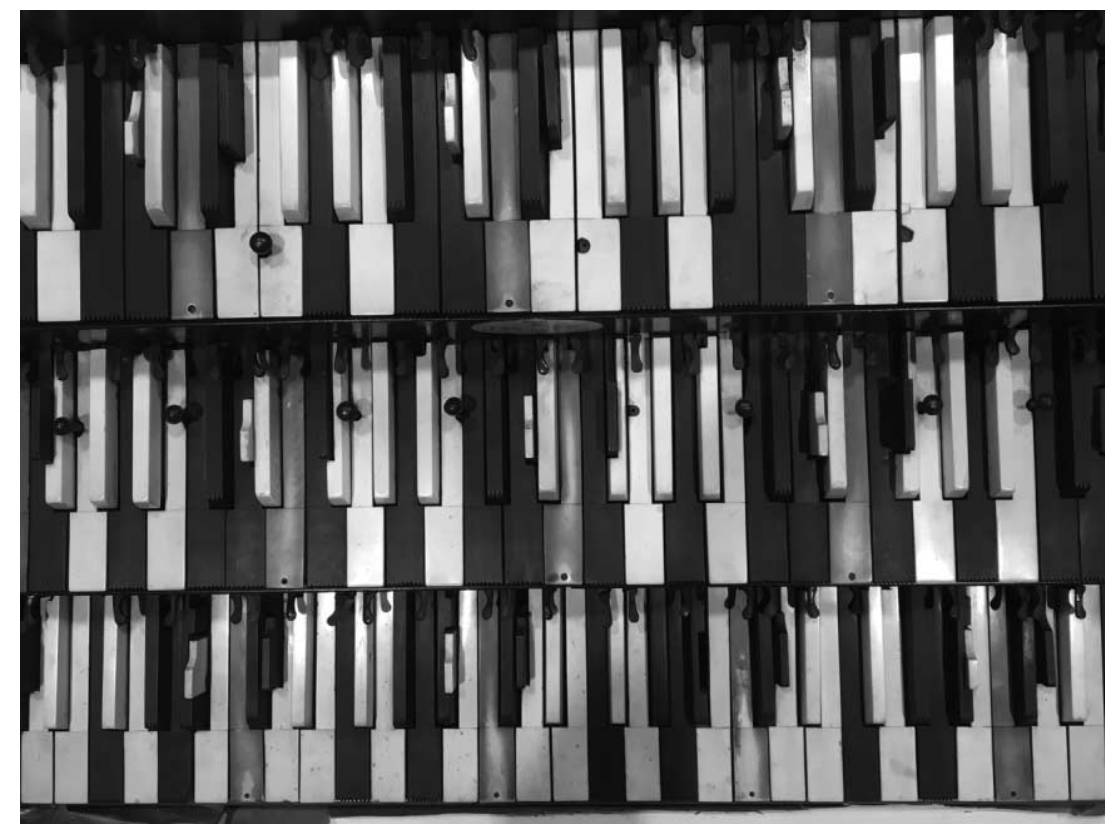

Figure 2. The keyboard of General Thomas Perronet Thompson's enharmonic organ, ca. 1850-67. Courtesy of the Science Museum, London. Photo credit: Daniel Walden.

Thompson also illustrated the magnitudes of intervals in his tuning system in a diagram he called "the canonical circle." Fifty-three "indices" placed around the circumference represent the division of the octave into fifty-three equal parts. His "Index Scale" represented the just intonation scale by reference to the sound indices that corresponded most closely. Thompson explains that although his instrument is precisely tuned in just intonation, not fifty-three-tone equal temperament, this method serves a practical function by helping the musician "obtain[] command over the calculation and comparison of the just intervals" by addition or subtraction: thus the index of the fourth (22) added to the index of the major third (17) equals 39, or the index of the major sixth. ${ }^{21}$ Like Alexander Ellis's system of musical cents, invented several decades later, the fifty-third division of the octave could serve a basic musical quantum that was small enough to work as a metrical device for all commonly used varieties of intervals. ${ }^{22}$ This concept can also be understood as a natural outgrowth of a Victorian

21. T. P. Thompson, Theory and Practice of Just Intonation: With a View to the Abolition of Temperament (London: Effingham Wilson, 1850), 17.

22. Thompson does not mention that fifty-three-tone equal temperament has a long global history as a resource for quantifying intervals, appearing in treatises by ancient treatises by Philolaus and Jing Fang, as well as in early modern texts by Athanasius Kircher, Marin Mersenne, Isaac Newton, Nicolaus Mercator, and William Holder. See Barbieri, Enharmonic Instruments, 350-51. 
THE PICTORIAL CIRCLE.

43. A good way of displaying the comparative magnitudes of the just

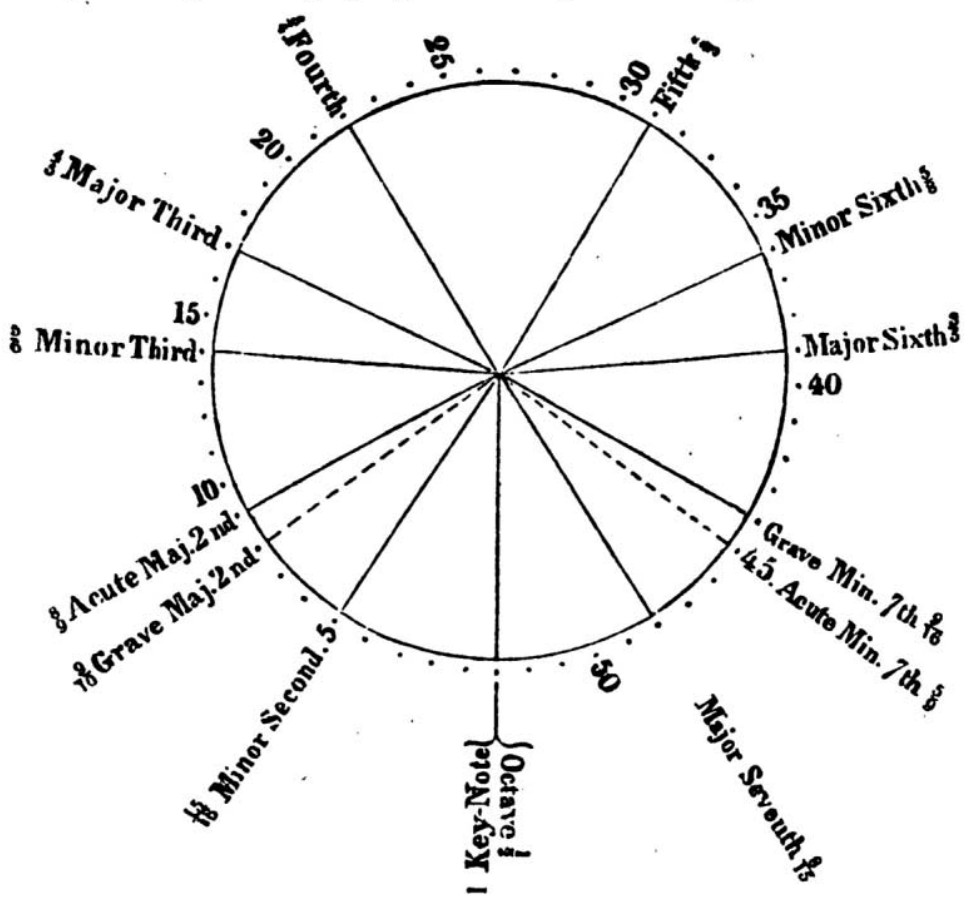

Figure 3. T. P. Thompson's canonical circle, from Theory and Practice, 16.

intellectual culture that placed a premium on objective metrics for use in data collecting and archival bookkeeping, both of which were also essential tools for colonial governance. ${ }^{23}$ Thanks to Thompson's system, music too could now be stored in tables, records, and logs in a manner that would subsequently allow for comparative analysis - a project similar to what Ellis undertook in his seminal 1885 study "On the Musical Scales of Various Nations," which played a key role in the development of comparative musicology.

Perhaps the most striking feature of Thompson's organ, however, was the keyboard itself: a "seeming wilderness of manuals and sounds" whose difficulty could only be "met gradually and by an orderly process," a prescription he followed to teach his granddaughter Edith and her cousin Laura to play. ${ }^{24}$ The forty-two divisions of the oc-

23. For related thoughts on the conceptual basis of colonial bookkeeping, see, among others, Lisa Lowe, The Intimacies of the Four Continents (Durham, NC: Duke University Press, 2015).

24. Thompson, Theory and Practice, 22. 
tave were split across three manuals, the bottom of which was centered on the $\mathrm{C}$ major just-intonation scale, the middle on E major, and the top on D major. The extra digitals required to provide access to the maximal number of just-intonation keys were inserted between the conventional twelve diatonic keys and raised sharps of the keyboard, and comprised a variety of bar-shaped "quarrels" (or "quarrills"), tab-shaped "flutals," and round "buttons," all variously colored in a mix of black, white, red, and gold. This arrangement appeared cumbersome, but for Thompson, that was precisely the point. It would discourage performers from engaging in an overly individualistic virtuosity that was not in sympathy with communal choral practices. In an exchange with the American enharmonicist Henry Ward Poole, the inventor of several just-intonation organs installed in churches throughout the Boston area during the 1840s-50s, Thompson also explained that the "merits" of his manuals were that in order to be able to play them, the musician was "compell[ed .. .] to know what he is doing." 25

The main objective of the keyboard design, in other words, was to break down the cultural habits of equal temperament and guide a new generation of pupils quite literally by the hand toward an enlightened musical sensibility and theoretical understanding. In this sense, Thompson was aiming at what Vladimir Jankélévitch has called the "reverse shock" of the musical "tool on the worker" and what Carolyn Abbate has further elaborated as the recognition that "musical instruments themselves- how they work, their material possibilities and the gestures they enable, and what they feel like under one's hands - have a greater effect on compositional choices than the composer's abstract ideas about what the piece should be or how it should unfold." 26 Directed by a series of physical cues that Thompson had placed on the keyboard, including circles carved out of the red "tonic keys" and ridges placed on the edges of specific scale degrees on each manual, even blind organists purportedly needed only six lessons before acquiring the ability to perform upon it. This experience demonstrated for Thompson that the most effective form of just-intonation pedagogy was to guide the body before the intellect, retraining the sensibilities of touch and hearing through the process of apperception and thereby re-forming a subject to be more readily disposed to a musical theory that promotes modern civilization.

25. Henry Ward Poole, "On Perfect Harmony in Music, the Double Diatonic Scale, and an Enharmonic Key-Board for Organs, Piano-fortes, etc.," American Journal of Science and Arts 2/44, no. 130 (1867): 7-8.

26. Vladimir Jankélévitch, Music and the Ineffable, trans. Carolyn Abbate (Princeton, NJ: Princeton University Press, 2003), 27-28; Carolyn Abbate, "Sound Object Lessons," Journal of the American Musicological Society 69, no. 3 (2016): 803. 
TANAKA'S PURSUIT OF THE "GREAT CAUSE"

In 1890, several decades after Thompson's instrument had fallen into relative obscurity, the twenty-eight-year-old Japanese physicist, acoustician, and music theorist Tanaka Shōhei made a personal call on the well-known composer Anton Bruckner to introduce him to a just-intonation "mathematical harmonium" he had devised. After informing Bruckner of his credentials as a student of acoustics with Hermann von Helmholtz and music theory with Phillipp Spitta for the past six years, Tanaka persuaded the composer to accompany him in a wagon he had left waiting outside the front door to the Japanese Embassy, to see the harmonium in action. Bruckner's student Friedrich Eckstein, who joined them on this excursion, later recounted the details of Tanaka's demonstration, which began with a performance of the prelude to Wagner's Lohengrin:

While he occasionally hesitated, the impression was very surprising and overwhelming, and when he played the same piece on an ordinary harmonium in equal temperament that was standing nearby, we had the impression that this instrument was unbearably out of tune. This demonstration began to interest Bruckner ever more. He wrote down several enharmonic chord progressions . . . then Dr. Tanaka sat down at the instrument and we now had the singular pleasure of having all those otherwise only ideal, purely cerebral reinterpretations demonstrated now in real life by clearly discernible tone steps! Bruckner . . . basked in the pleasure of all possible pure chord connections. ${ }^{27}$

Bruckner was only one of many musicians for whom Tanaka demonstrated his instrument: Joseph Joachim, Carl Reinecke, Heinrich von Herzogenberg, Kaiser Wilhelm II, and the entire faculty of the Royal Conservatory of Music at Leipzig recalled their pleasure at hearing musical "ideals" realized in the physical world..$^{28}$ Most effusive of all was

27. "Obwohl er mitunter stockte, war der Eindruck doch höchst überraschend und überwältigend, und als er hierauf dasselbe Stück auf einem daneben stehenden gewöhnlichen Harmonium in gleichschwebend temperierter Stimmung vortrug, hatten wir den Eindruck, daß dieses Instrument unerträglich verstimmt sei. Bruckner, den diese Vorführung nun immer mehr zu interessieren begann, schrieb einige enharmonische Akkordverbindungen nieder . . . setzte sich [Dr. Tanaka] an sein Instrument und nun hatten wir den einzigartigen Genuß, alle jene sonst nur ideellen, rein gedanklich vorgenommenen Umdeutungen, jetzt in voller Wirklichkeit, durch deutlich hörbare Tonschritte und Tastenwechsel vorgeführt zu erhalten! Bruckner ... schwelgte in dem Genusse aller möglichen reinen Akkordverbindungen" (Friedrich Eckstein, Erinnerungen an Anton Bruckner [Vienna: Universal Edition, 1923], 39-40).

28. Franz Schulz et al., Testimonials, etc. (Translations) Relating to the "Enharmonium," Invented by Shohé Tanaka (London: Unwin Brothers, 1891). 




Figure 4. The keyboard to Tanaka Shōhei's enharmonium. Photo credit: Kazuhiko Shima, Director of the Hamamatsu Museum of Musical Instruments. Color version available as an online enhancement.

Hans von Bülow, who gave the instrument a name that paid homage to its novel harmonic capabilities: the enharmonium (fig. 4). ${ }^{29}$

Tanaka's pathway to the invention of the enharmonium was in many ways remarkable. After graduating from the University of Tokyo in 1882 at only twenty years old, Tanaka received a scholarship from the Meiji Ministry of Education to further his studies abroad. He joined the ranks of an elite group of government-sponsored Japanese overseas students (ryūgakusei) selected for their willingness to serve as "modernizers" upon their return, assisting the Japanese nation in its transition from isolated feudalism to a modern imperialism. Among the thousands of overseas scholarships that had been awarded so far, Tanaka's was one of the first granted for the study of music and acoustics in Berlin. He arrived in 1884 with six colleagues, joining a vibrant network of Japanese overseas students based in Berlin, who arranged social gatherings, mutual support societies, interest clubs, and musical events that featured mixed programs of traditional and indigenous Japanese songs alongside the latest popular European repertoire. ${ }^{30}$ His activities put him in close touch with Hans von Bülow,

29. Shohé Tanaka [Tanaka Shōhei], "Studien im Gebiete der reinen Stimmung," Vierteljahrsschrift für Musikwissenschaft 6, no. 1 (1890): 23.

30. For more, see Hoi-Eun Kim, Doctors of Empire: Medical and Cultural Encounters Between Imperial Germany and Meiji Japan (Toronto: University of Toronto Press, 2014). Kim estimates that at least 25,000 Japanese students studied overseas between 1866 and 1914 (ibid., 55). 
340 I HISTORY OF HUMANITIES FALL 2017

who lauded him as a "glorious reformer" of European music by helping it shed "unchaste contortion, convulsion, and confusion." ${ }^{31}$ By working to reform German performance practice during his time abroad, with the ambition of transforming Japanese musical performance practices upon his return home, Tanaka became a key figure in the development of transnational links between two nations increasingly interconnected in a shared quest for a music theory suited to a globalist modernity.

Enrolled at both the University of Berlin and the Stern Konservatorium, Tanaka vowed above all to "espouse the great cause of pure tuning with determination and dignity." 32 His research picked up where his advisor Helmholtz had left off: the demonstration that traditional equal temperament should be deemed responsible for "unpleasant symptoms for the further development of art," by preventing the development of "full harmoniousness." 33 Helmholtz had earlier invented a just-intonation instrument he called the "reinharmonium," featuring twenty-four divisions of the octave and designed for scientific experiments and the instruction of choirs in correct intonation. For Tanaka as for Helmholtz, the recognition of just intonation's importance was fraught with urgency. Musical culture had to be rescued from the corruption of a musical temperament that concealed what was in fact modern, natural, easier, and purer. He aimed to complete what Helmholtz had begun by developing a keyboard that was practical not just for research but also for performance, for "liberat[ing music] from the unpleasant effects of an artificial temperament" to make sensible its "natural purity and harmonic logic" as demonstrated by scientific theory. ${ }^{34}$

For his promotional tour, Tanaka published his "Studien im Gebiete der reinen Stimmung," which situates the enharmonium in a detailed musicological survey of the history of enharmonic and microtonal instruments. His instrument was rendered more practical than its predecessors, including Thompson's keyboards, by a virtue of a transposing keyboard that could be shifted to the right or left as far as six semitones. The twenty digitals on Tanaka's keyboard are also accompanied by a knee lever that

31. Schulz et al., Testimonials, 8. Bülow's statement must not be divorced from its context following a series of anti-Asian and anti-Semitic remarks.

32. "damit ich die grosse Sache der reinen Stimmung mit Entschlossenheit und Würde immer noch vertrete" (Letter from Tanaka Shōhei to Oskar Walcker, December 30, 1892, quoted in Martin Vogel, On the Relations of Tone, trans. Vincent Jean Kisselbach [Bonn: Verlag für Systematische Musikwissenschaft, 1993], 332).

33. Hermann L. F. Helmholtz, On the Sensations of Tone as a Physiological Basis for Music, 2nd English ed., trans., rev., and corr. Alexander J. Ellis (London: Longman, Greens, 1885), 327, 428.

34. "befreit von jenen unangenehmen Wirkungen der künstlichen Temperatur-in ihrer natürlichen Reinheit und harmonischen Folgerichtigkeit wiedergegeben werden" (Tanaka Shōhei, "Introduction," in Enharmonium: Sammlung kleiner Vortragsstücke für das reingestimmte Harmonium nach dem System des Dr S. Tanaka, ed. Gustav Papendick [Leipzig: Breitkopf \& Härtel, 1891], iii). 
switches the backs of the sharps to six enharmonic alternatives, granting the performer access to the sixteen major and minor keys that are then automatically transposed to any of twelve different pitch levels. The design is not only expedient and more exactly tuned, but it also allows the performer to grasp the musical structure immediately, for " $\mathrm{C}$ always symbolizes the tonic, $\mathrm{D}$ the supertonic, and $\mathrm{E}$ the mediant of the primary key." ${ }^{35}$ Tanaka's keyboard, like Thompson's, thus aims to harness the "reverse shock" of the interaction with the instrument as a pedagogical method by inviting the acquisition of embodied analytical insights through the hands: "since harmonic progressions are always notated in the same manner as the same combinations of intervals and executed by the same keys, the performer's understanding of harmonic structure of musical works is greatly encouraged" (fig. 5). ${ }^{36}$

The enharmonium was accompanied by a collection of short canonical works from the Renaissance to the late Romantic, assembled in collaboration with Professor Gustav Papendick from the Stern Konservatorium and featuring notational strikes that indicate enharmonic differences. The album opens with Robert Schumann's "Stückchen" from Album für die Jugend, opus 68, followed directly by Papendick's own "Für meine Kleine." Papendick's composition is clearly in direct imitation of Schumann's, updating his simple harmonic syntax with chromatic and enharmonic modulations that lead to unexpected new harmonic areas, such as in measure 12, where Papendick echoes the tail end of the previous phrase, a syntonic comma lower (approximately equivalent to an eighth tone), at a pianissimo whisper. In remarkable passages like these, Papendick reveals that the enharmonium not only improves the performance of already composed works by lending them a sensual richness unimaginable up until then but also prompts musicians to place on the very surface of the musical texture the enharmonic features that Kinkel had noticed were previously submerged. The immediate juxtaposition of these two works suggests that a fully "liberated" Schumann would have written music containing enharmonic passages such as these, for he would have been able to travel further down the "unknown pathways" extending across the terrain of universal musical nature.

The closest thing to a theoretical map of this terrain appears at the outset of Tanaka's treatise, in a description of the mathematical properties of the just intonation system

35. "die Note c immer die Tonika, die Note d die Sekunde, die Note e die Terz u.s.w. der Hauptdurtonart bedeutet" (Tanaka, "Studien," 23).

36. "da dieselben harmonischen Wendungen immer von denselben Kombinationen der stets in derselben Weise notirten und mit denselben Tasten zur Ausführung gelangenden tonartlichen Intervalle begleitet werden, das Verständniß des harmonischen Baues der Musikwerke bedeutend erleichtert wird" (ibid., 22-23). 
Stückchen.

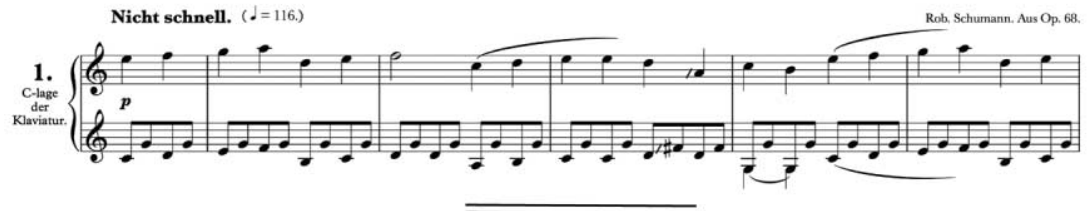

Für meine Kleine.


Figure 5. The opening bars of Robert Schumann's "Stückchen," compared with Gustav Papendick's "Für meine Kleine," from Sammlung, 2-3. 


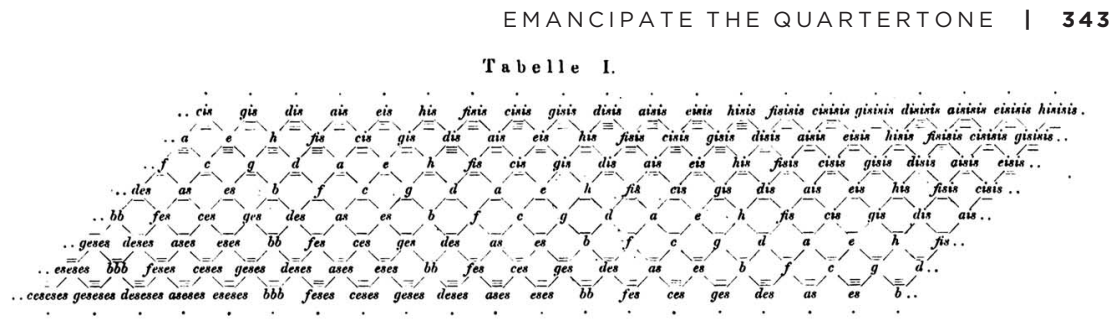

Figure 6. Tanaka's Tongewebe, from "Studien," 5.

featured on his instrument. His table 1 depicts the hexahedrical Tongewebe, illustrating an "ideal, boundless" network of individual tones—or "sound atoms," to borrow Kinkel's phrase - arranged in rows of perfectly tuned fifths separated by perfectly tuned major thirds set at a diagonal angle from one another (see fig. 6). ${ }^{37}$

Tanaka's quest to describe the operations of this "ideal, boundless" field of tones recalls contemporary efforts by figures, including Alexander Ellis, to develop an International Phonetic Alphabet (IPA) that could serve for instruction in all global languages. ${ }^{38}$ Just as the IPA provides a universal collection of phonemes enabling the transcription of Japanese, German, or any other language in a predominantly Latin script, the Tongewebe provides a universal collection of tones enabling the transcription of global musics into a fundamentally Western notation. The Tongewebe thus points toward the eventual endpoint of the enharmonic theoretical transformation: a new music theory focused on global modernity. It would be modern in that it would seek to understand music as constructed by sequences of individual notes, like atomic particles, that were combined in various permutations to form both melody and harmony; it would be globalist in that it would enable cross-cultural comparison of how these sonic particles were combined in different ways. The revolution in music theory that Kinkel heralded, and that Thompson had pursued before him, would be worldwide in Tanaka's formulation, with musical traditions from around the globe interwoven into a single theoretical just-intonation network that was in tune with the modern politics of transnational exchange.

37. For more on the use of this diagram by Hugo Riemann and others, see Richard Cohn, "Tonal Pitch Space and the (Neo-)Riemannian Tonnetz, in The Oxford Handbook of Neo-Riemann Music Theories, ed. Alexander Rehding and Edward Gollin (Oxford: Oxford University Press, 2011): 322-50.

38. Tanaka was in fact actively involved in phonetic research at the time. He was a key member of the "Klub für lateinische Schrift," or Romaji-kai, an association of Japanese students in Berlin who sought to develop an alternative to the preexisting Hepburn method for transcribing Japanese in Roman script. See Mori Ōgai, Deutschlandtagebuch 1884-1888, trans. Heike Schöche (Tübingen: Konkursbuch Verlag Claudia Gehrke, 1992), 43. 


\section{WORKS CITED}

Abbate, Carolyn. 2016. "Sound Object Lessons." Journal of the American Musicological Society 69, no. 3:793-829.

Barbieri, Patrizio. 2008. Enharmonic Instruments and Music 1470-1900. Rome: Il Levante Libreria Editrice.

Cohn, Richard. 2011. "Tonal Pitch Space and the (Neo-)Riemannian Tonnetz." In The Oxford Handbook of Neo-Riemannian Music Theories, edited by Edward Gollin and Alexander Rehding, 322-50. Oxford: Oxford University Press.

Conti, Luca. 2005. Suoni di una terra incognita: Il microtonalismo in Nord America (1900-1940). Lucca: Libreria musicale italiana.

Dickens, Charles, and Richard Horne. 1851. "The Great Exhibition and the Little One." Household Words 3, no. 67:356-60.

Eckstein, Friedrich. 1923. Erinnerungen an Anton Bruckner. Vienna: Universal Edition.

Helmholtz, Hermann L. F. 1885. On the Sensations of Tone as a Physiological Basis for Music. Translated, revised, and corrected by Alexander J. Ellis. 2nd English ed. London: Longman, Greens.

Jankélévitch, Vladimir. 2003. Music and the Ineffable. Translated by Carolyn Abbate. Princeton, NJ: Princeton University Press.

Johnson, Leonard George. 1957. General T. Perronet Thompson, 1783-1869. London: George Allen \& Unwin.

Kim, Hoi-Eun. 2014. Doctors of Empire: Medical and Cultural Encounters between Imperial Germany and Meiji Japan. Toronto: University of Toronto Press.

Kinkel, Johanna. 1852. Acht Briefe an eine Freundin über Klavier-Unterricht. Stuttgart: J. B. Cotta.

_. 1902. "Chopin als Komponist.” Deutsche Revue 27 (January-March): 93-106, 209-23, 338-69.

Klaus, Monica. 2008. Johanna Kinkel: Romantik und Revolution. Cologne: Böhlau.

Lowe, Lisa. 2015. The Intimacies of Four Continents. Durham, NC: Duke University Press.

Official Catalogue of the Great Exhibition of the Works of Industry of All Nations. 1851. 2nd ed. London: Spicer Brothers.

Ōgai, Mori. 1992. Deutschlandtagebuch 1884-1888. Translated by Heike Schöche. Tübingen: Konkursbuch Verlag Claudia Gehrke.

Papendick, Gustav A., ed. 1891. Enharmonium: Sammlung kleiner Vortragsstücke für das reingestimmte Harmonium dem System des Dr S. Tanaka. Introduced by S. T. [Tanaka Shōhei]. Leipzig: Breitkopf \& Härtel.

Poole, Henry Ward. 1867. "On Perfect Harmony in Music, the Double Diatonic Scale, and an Enharmonic Key-Board for Organs, Piano-fortes, etc.” American Journal of Science and Arts 2/44, no. 130:1-22.

Riehl, Wolfgang Heinrich. 1855. Hausmusik. Stuttgart: J. G. Cotta.

Schulz, Franz, et al. 1891. Testimonials, Etc. (Translations) Relating to the "Enharmonium," Invented by Shohé Tanaka. London: Unwin Brothers.

Siegel, Linda. 2003. "Johanna Kinkel's 'Chopin als Komponist' and Other Musical Writings: Untapped Source Readings in the History of Romantic Music." College Music Symposium 43:105-25.

Tanaka, Shohé [Tanaka Shōhei]. 1890. "Studien im Gebiete der reinen Stimmung." Vierteljahrsschrift für Musikwissenschaft 6, no. 1:1-90.

Thompson, T. P. 1842. Exercises, Political and Others. Vol. 2. London: Effingham Wilson.

1850. Theory and Practice of Just Intonation: With a View to the Abolition of Temperament. As illustrated by the Description and Use of the Enharmonic Organ. . . London: Effingham Wilson.

Turner, Michael. 2004. Independent Radicalism in Early Victorian Britain. Westport, CT: Praeger.

Vogel, Martin. 1993. On the Relations of Tone. Translated by Vincent Jean Kisselbach. Bonn: Verlag für Systematische Musikwissenschaft. 